УДК 631.543.83

\title{
ОБЗОР РАЗНОВИДНОСТЕЙ РАБОЧИХ ЗВЕНЬЕВ УСТАНОВОК ДЛЯ ИЗМЕЛЬЧЕНИЯ РАСТИТЕЛЬНОСТИ
}

\author{
Губанова Алина Дмитриевна \\ аспирант \\ ФГБОУ ВО РГАТУ
}

\begin{abstract}
Аннотация: Данная статья написана с целью выбора оптимального устройства для первоначальной подготовки лиственного материала для его дальнейшего преобразования. Приведены основные существующие механизмы для измельчения растительной массы. Дана характеристика каждого типа, его применимость для измельчения опавшей листвы.

Ключевые слова: Виды измельчителей, рабочие органы измельчителя, измельчители, измельчение опавшей листвы, измельчение растений, измельчение листьев, измельчение травы.
\end{abstract}

\section{OVERVIEW OF THE TYPES OF WORKING LINKS OF PLANTS FOR CRUSHING VEGETATION}

\section{Gubanova Alina Dmitrievna}

Abstract: This article presents the main existing mechanisms for grinding plant mass. The characteristics of each type, as well as its applicability for crushing fallen leaves, are given.

Key words: Types of shredders, working bodies of the shredder, shredders, shredding of fallen leaves, shredding of plants, shredding of leaves, shredding of grass.

В сельскохозяйственной промышленности, на садовых участках мы часто сталкиваемся с вопросом измельчения растительности. Данный вид преобразования растительного материала становится прекрасной альтернативой обычному способу утилизации такому как, например, транспортировка в места сбыта. Измельчение также применяется как предварительный этап подготовки сырья для его дальнейшего преобразования. Данная статья написана с целью 
выбора оптимального устройства для измельчения опавшей листвы для дальнейшего ее экструдирования. При этом степень измельчения должна быть не более 10 мм [2, с.10].

Струнный тип. В таком виде измельчение происходит при помощи лески. Леска быстро вращается, мелко измельчая материал. Измельчающие органы данной установки представлены на рисунке 1. Она подходит для травы, листьев, однако при работе с таким видом измельчителя стоит тщательно просматривать материал на наличие веток и мелких камней, т.к. при их попадании детали выйдут из строя. Данная установка может подойти для измельчения опавшей листвы, однако наличие большой вероятности попадания посторонних предметов подталкивает сделать выбор в пользу другого типа измельчителя [3, с. 7].

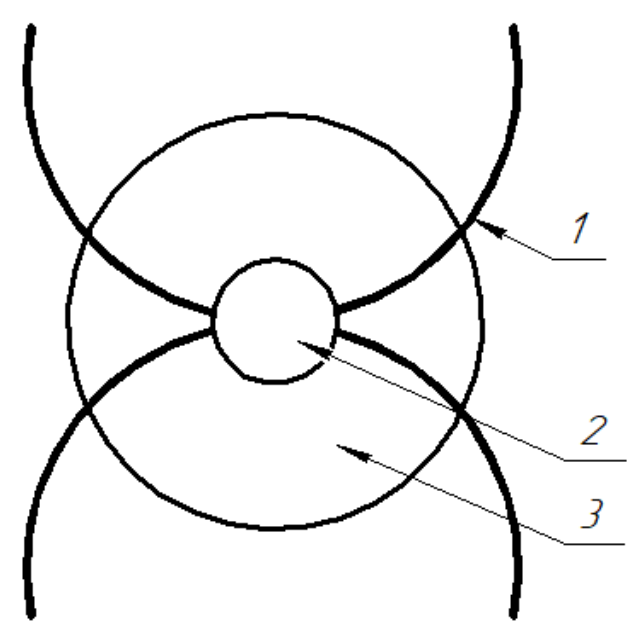

Рис. 1. Рабочие органы струнного измельчителя

1- режущая леска; 2 - элементы крепления; 3 - элементы привода

Следующий вид, который будет рассмотрен в данной статье молотковый. Пример рабочих органов такого вида измельчителя представлен на рисунке 2. Он чаще всего применяется для измельчения зерновой части урожая, данный вид измельчителя будет нецелесообразно применять для измельчения лиственного материала, потому что работа данного устройства обусловлена большими энергозатратами. 


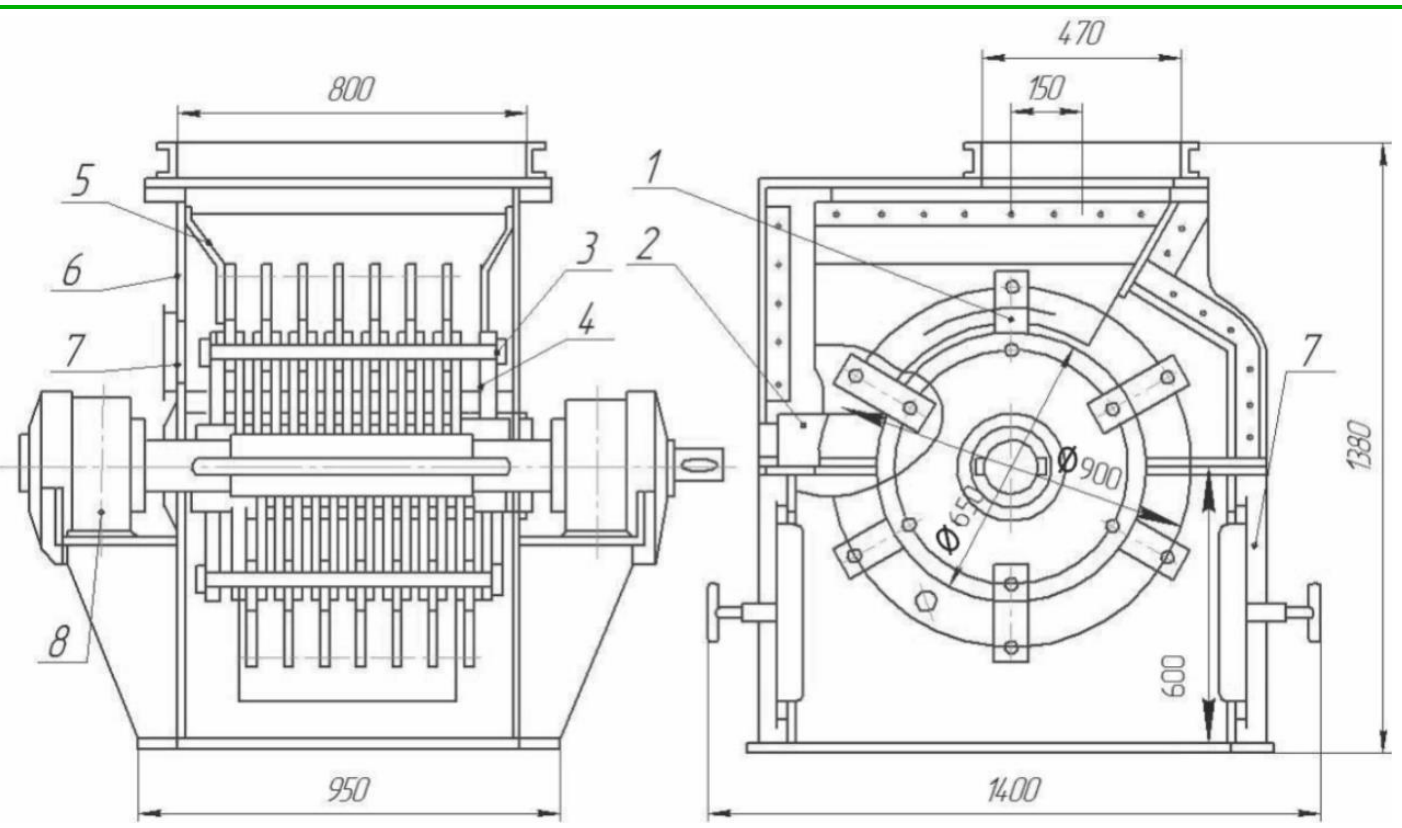

Рис. 2. Молотковый измельчитель (зернодробилка)

1- молотки; 2 - отбойный нож; 3 - оси; 4 - стойки; 5 - дробилка; 6- стенки корпуса; 7-люки; 8- опоры [1, с. 46].

Измельчитель, рабочим органом которого является ножевой блок (рисунок 3), подходит для измельчения толстых стеблей, небольших веток диаметром до 2 сантиметров. Наиболее надежными считаются модели, в которых ножи оснащены двусторонним лезвием. Техническое обслуживание такого устройства достаточно простое, при затуплении режущего элемента, достаточно просто сменить ножи. Для лиственного материала данный агрегат подходит, однако из-за низкой степени измельчения и небольшой производительности при работе с данным материалом применять его не целесообразно.

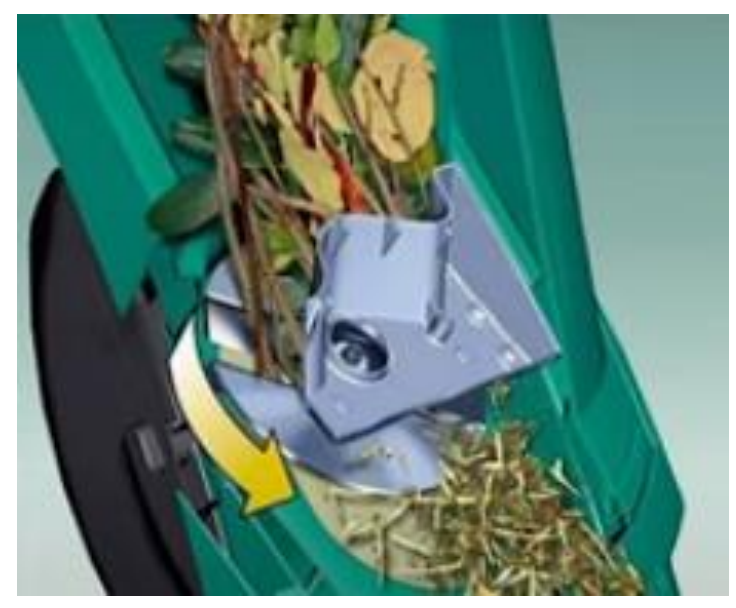

Рис. 3. Схема ножевого блока измельчителя 162 


\section{НАУКА, ОБЩЕСТВО, КУЛЬТУРА: ПРОБЛЕМЫ И ПЕРСПЕКТИВЫ ВЗАИМОДЕЙСТВИЯ В СОВРЕМЕННОМ МИРЕ}

Наиболее эффективным является измельчитель центробежно-роторноножевого типа [пат. RU №2270057, В02C 13/20, приоритет 17.06.2004], предназначенный для измельчения растительного сырья и сыпучих материалов, имеющий корпус, в котором горизонтально и соосно установлены два диска с чередующимися кольцевыми выступами, в которых в радиальном направлении выполнены сквозные пазы, при этом камера измельчения содержит две ступени [2]. При подобном способе листва будет проходить две стадии измельчения. Степень измельчения при таком способе будет оптимальной для дальнейшего преобразования листвы.

Существует измельчитель, в котором рабочим органом является шестерня (рис. 4), оборудованная острой зубчатой поверхностью. Такой вид измельчителя подходит для толстых веток, диметром более 2 сантиметров. Работает данное устройство следующим образом: при проталкивании древесины в загрузочный бункер, материал попадает на вращающийся шестеренчатый механизм, который преобразует материал в щепки. Данное устройство не подходит для лиственного материала.

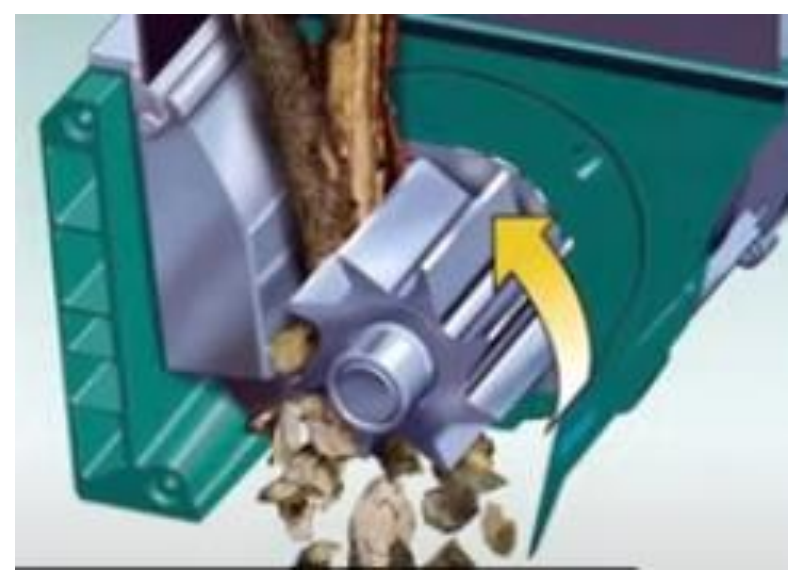

\section{Рис. 4. Шестеренчатый механизм для измельчения веток}

Следующий вид измельчителя, рассматриваемого в данной статье турбинный. Рабочий орган данного устройства выполнен в виде перфорированной цилиндрической поверхности из тугосплавного материала (рис. 5), оснащенной ножами-лопатками, расположенными под определенным углом. При вращении данного органа лопатки приподнимают измельчаемый материал, а ножи выполняют измельчение. Данное устройство хорошо подходит для измельчения опавшей листвы, при этом можно использовать без опасений попадания древесного мусора или мелкого щебня. 


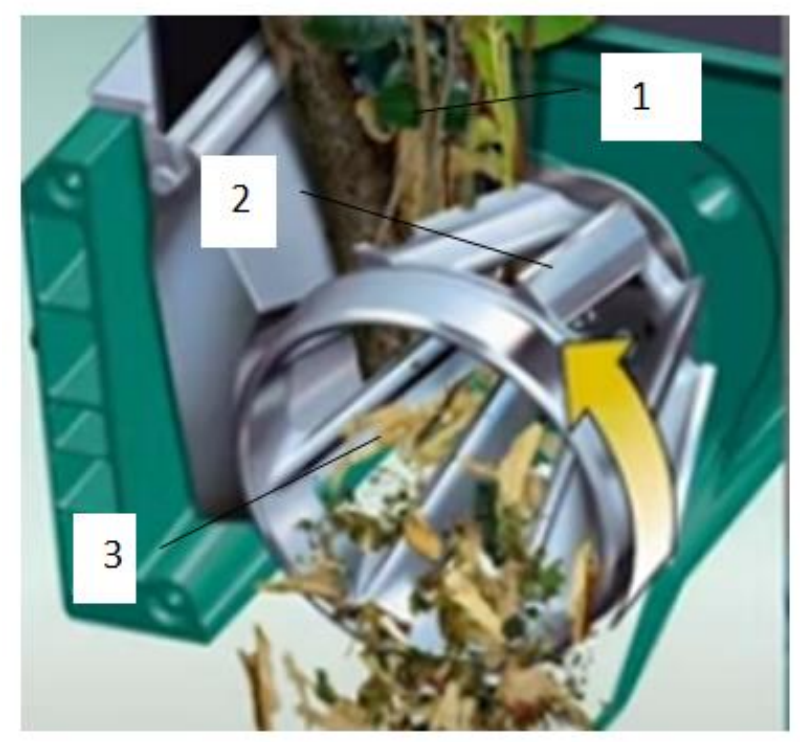

Рис. 5. Измельчающее устройство турбинного измельчителя

\section{1-измельчаемы материал; 2-лопатки-ножи; 3-турбинный измельчитель}

На основании рассмотренных выше типов установок для измельчения можно сделать вывод, что для преобразования листвы, опавшей с деревьев, лучше всего подойдут измельчители турбинного или центробежно-роторноножевого типа. Данные агрегаты надежны и просты в обслуживании. Турбинный измельчитель подойдет для предварительного измельчения, затем необходимо использовать центробежно-роторно-ножевого типа, так как фильеры в фильтрах можно устанавливать нужного диаметра, таким образом, лиственный материал, проходя стадии измельчения, станет пригодным для дальнейшего экструдирования.

\section{Список литературы}

1. Горфин О.С., Михайлов А.В. Машины и оборудование по переработке торфа. Часть 1. Производство торфяных брикетов. Учебник. Изд. второе дополненное и переработанное - Тверь. ТвГТУ, 2013. 226 с.

2. Пахомов В.И., Брагинец С.В., Алферов А.С., Бахчевников О.Н., Бенова Е.В., Рухляда А.И., Чернуцкий М.В. Технологический регламент экструдирования смеси зерновых и зеленых кормов при внутрихозяйственном приготовлении комбикормов. - Зерноград: ФГБНУ АНЦ «Донской», 2017. $60 \mathrm{c}$

3. Мясищев Д.Г., Яхяев Д.Б., Морозов В.С. Оценка процесса измельчения напочвенного покрова струной // Лесн. журн. №5 С- Изв. высш. учеб. заведений, 2018 